\title{
Biochar Improves Sustainability of Green Roofs via Regulate of Soil Microbial Communities
}

\author{
Haoming Chen ${ }^{1, *}$, Xianfeng Du ${ }^{1}$, Mengqi Lai ${ }^{1}$, Muhanmaitijiang Nazhafati ${ }^{1}$, Chen Li ${ }^{1}$ and Weicong Qi ${ }^{2, *(D)}$ \\ 1 School of Environmental and Biological Engineering, Nanjing University of Science and Technology, \\ Nanjing 210094, China; dxf_hnzjj@163.com (X.D.); Rupaduzi@163.com (M.L.); nazhafati@163.com (M.N.); \\ lichen46@njust.edu.cn (C.L.) \\ 2 Institute of Agricultural Resources and Environment, Jiangsu Academy of Agricultural Sciences, \\ Nanjing 210014, China \\ * Correspondence: chenhaoming@njust.edu.cn (H.C.); weicong_qi@163.com (W.Q.); \\ Tel.: +86-15105185117 (H.C.); +86-13913013421 (W.Q.)
}

Citation: Chen, H.; Du, X.; Lai, M.; Nazhafati, M.; Li, C.; Qi, W. Biochar Improves Sustainability of Green Roofs via Regulate of Soil Microbial Communities. Agriculture 2021, 11, 620. https://doi.org/10.3390/ agriculture 11070620

Academic Editors: Zakaria Solaiman and Hossain Md Anawar

Received: 9 June 2021

Accepted: 26 June 2021

Published: 1 July 2021

Publisher's Note: MDPI stays neutral with regard to jurisdictional claims in published maps and institutional affiliations.

Copyright: (C) 2021 by the authors. Licensee MDPI, Basel, Switzerland. This article is an open access article distributed under the terms and conditions of the Creative Commons Attribution (CC BY) license (https:// creativecommons.org/licenses/by/ $4.0 /)$.

\begin{abstract}
Green roofs are an important part of urban green spaces. A good roof soil system contributes to the stability of the green roof ecosystem in harsh environments. Biochar as a soil additive can improve soil nutrients, although the mechanism of improvement on the roof substrate is still unclear. This research studied the effects on the physical and chemical properties of green roof soil and analyzed the biological characteristics of green roofs at five gradient ratios of biochar addition $(0 \%$, $5 \%, 10 \%, 15 \%$ and $20 \%$ biochar; $v / v)$. The results indicated that biochar could improve the soil porosity (5.3-9.3\%) and reduce the bulk density (3.9-10.8\%); increase the soil moisture (14.0-37.2\%); adjust the temperature, available nutrients and cation exchange capacity (38.1-75.9\%) and regulate the soil $\mathrm{pH}$ values of the green roof. The biomass of soil microbes, eukaryotes and plants were increased by $75.3 \%, 199.2 \%$ and $57.5 \%$, respectively. Meanwhile, the correlation between microbial diversity and soil nutrients was more significant due to the addition of biochar, and the increase of the phosphorus $(\mathrm{P})$ and carbon $(\mathrm{C})$ contents was the main factor affecting the microbial community. The structural equation model showed that biochar has a direct impact on the microbial diversity by improving the soil moisture, temperature and available nutrients, and the increase of the microbial diversity is conducive to plant growth. Summarily, biochar can be considered as a potential additive for roof soil amendment and promoting the growth of plants and microbes, which is beneficial to the development of a roof ecosystem.
\end{abstract}

Keywords: sludge biochar; roof soil properties; microbial biomass; available nutrients; reducing soil consumption

\section{Introduction}

Green roofs have become increasingly popular for their contribution to improving the urban environment, such as reducing rainwater runoff, saving energy consumption in construction, absorbing harmful gases, particulate matter, improving the development of urban agriculture, etc. [1-7]. In addition, improving green roof facilities can increase the availability of natural ecological areas, thereby providing new habitats for wildlife [8,9] and enriching urban biodiversity [5]. The green roof ecosystem services derive from two main components of the living roof system: substrate (growing medium; main component is soil) and plants [5]. The existing research has focused on the allocation of plants and the management of roof rainwater [10-12]. However, the related research about the biological properties (microbes) of green roofs is very limited.

Soil microbial diversity and plant biomass are important indexes to evaluate the quality of a roof ecosystem. A preliminary study of green roof microbial communities showed that there were relatively few microbes in the roof soil; this might mean that the nutrient cycling efficiency of the soil is poor, especially in the absence of maintenance, 
resulting in a decline of plant growth and diversity [9]. Poor plant growth can lead to an unstable roof ecosystem and, hence, fail to achieve its ecological functions. Therefore, as the basis for realizing the ecological benefits of green roofs, the improvement of roof substrate properties and microbial diversity will be the hot spot of green roof research in the future.

Since the roof-planting environment is restrained by limited water, high temperatures and thin soil layers, the roof plants and microorganisms confront serious challenges in survival and growth [5,13-15]. Hence, selecting plant species for roof planting is important. For instance, Sedum lineare has proven to be suitable for green roofs because of its strong adaptability, but it still faces severe abiotic stress anyhow in the harsh environment of a roof $[10,16,17]$. Soil amendments help to improve the properties of roof substrates, thereby improving the plant growth environment. It could facilitate constructing a green roof and achieve ecological functions (like reducing the roof temperature, absorption of $\mathrm{CO}_{2}$, etc.) $[2,18]$. Meanwhile, a good roof soil environment is beneficial to enhance the biodiversity, promote the ecological balance and reduce the soil erosion of a green roof, which means it can also reduce the cost of maintenance and management [19]. Therefore, soil amendments have been gradually applied to green roofs. However, most of the existing roof soil amendments rely on inorganic materials (vermiculite, volcanic rock, broken brick, etc.) $[11,16,18]$. The use of municipal solid waste as a roof soil amendment is relatively rare.

Biochar is a kind of carbon-rich and stable product produced by pyrolysis and carbonization from a biomass [20-22]. It has a well-developed pore structure, relatively strong adsorption ability and high stability $[23,24]$. It can not only improve the soil structure, moisture, nutrient, organic matter content and promote plant growth [25-28] but, also, provide a good environment for the growth and reproduction of various microorganisms [19,29,30]. However, the application of biochar on green roofs is very rare.

Biochar has been widely studied as a soil amendment [25,30,31], although it not in the soil environments of green roofs. Thus, understanding the effects of biochar on roof soil can help to improve the diversity and stability of roof ecosystems. This investigation aimed to enhance the function of roof soil by adding sludge biochar (biochar) to increase the roof microbial diversity and plant growth. We hypothesized that biochar can significantly improve the moisture and nutrient contents of the roof soil, thus promoting the growth of the microorganisms and plants.

\section{Materials and Methods}

\subsection{Study Area and Materials}

This experiment was performed from July 2015 to June in 2016 on a roof (height $28 \mathrm{~m}$ ) of Nanjing Agricultural University $\left(118^{\circ} 51^{\prime} \mathrm{E}, 32^{\circ} 18^{\prime} \mathrm{N}\right)$. This area belongs to a subtropical monsoon climate. The average annual temperature of the area is $15.4^{\circ} \mathrm{C}$, the annual highest temperature is $43.1^{\circ} \mathrm{C}$ and the lowest temperature is $-14{ }^{\circ} \mathrm{C}$. The average annual precipitation is $1106.5 \mathrm{~mm}$ (Statistics time: 14 October 2019, official website of the Nanjing Municipal People's Government).

The sludge biochar treated by harmless drying and pyrolysis at $600{ }^{\circ} \mathrm{C}$ was produced by Mississippi International Water Ltd., Hangzhou, Zhejiang, China. The production details of the biochars can be referred to in our previous studies [19]. The local nature soil (Alluvial soil) was obtained from Pukou District in Nanjing, and it was air-dried, milled, sieved through a 50-mesh sieve $(0.3 \mathrm{~mm})$ and then used in the experiment. Alluvial soil has a certain amount of available nutrients, and it is suitable for plant growth (refer to Table 1). Sedum lineare (Sedum lineare Thunb.) was planted on the green roof, because it is the traditional green roof plant. According to the green roof construction guidelines of FLL Germany [32], most properties of biochar were significantly higher than that of soil, exemplified by the TC, TOC and other nutrients (Table 1). All the trace metal elements of the urban sewage sludge biochar were in line with the current national standard [33]; the heavy metal did not reach pollution levels. 
Table 1. Properties of the initial soil and biochar of the green roof before planting.

\begin{tabular}{|c|c|c|c|c|c|c|c|}
\hline Substrate & $\begin{array}{c}\text { BD } \\
\left(\operatorname{kg~L}^{-1}\right)\end{array}$ & $\mathrm{pH}$ & $\underset{\left(\mathrm{g} \mathrm{kg}^{-1}\right)}{\mathrm{TC}}$ & $\begin{array}{c}\text { TOC } \\
\left(\mathrm{g} \mathrm{kg}^{-1}\right)\end{array}$ & $\begin{array}{c}\mathrm{TN} \\
\left(\mathrm{g} \mathrm{kg}^{-1}\right)\end{array}$ & $\begin{array}{c}\text { TK } \\
\left(\mathrm{g} \mathrm{kg}^{-1}\right)\end{array}$ & $\begin{array}{c}\text { TP } \\
\left(\mathrm{g} \mathrm{kg}^{-1}\right)\end{array}$ \\
\hline Soil & $1.12 \pm 0.07$ & $8.32 \pm 0.01$ & $11.36 \pm 0.13$ & $9.59 \pm 0.05$ & $1.00 \pm 0.02$ & $1.36 \pm 0.01$ & $1.21 \pm 0.03$ \\
\hline Biochar & $0.97 \pm 0.09$ & $6.87 \pm 0.02$ & $243.38 \pm 0.38$ & $195.24 \pm 0.11$ & $1.73 \pm 0.03$ & $0.27 \pm 0.01$ & $1.71 \pm 0.03$ \\
\hline \multicolumn{8}{|c|}{ Metal contents $\left(\mathrm{mg} \mathrm{kg}^{-1}\right)$ of sludge biochar } \\
\hline \multirow{2}{*}{ Biochar } & $\mathrm{Cr}$ & $\mathrm{Cd}$ & $\mathbf{P b}$ & $\mathrm{Cu}$ & As & $\mathrm{Hg}$ & B \\
\hline & 172 & 1.42 & 55.2 & 1420 & 1.10 & 0.296 & 56.2 \\
\hline
\end{tabular}

Notes. Biochar was dried and dehydrated before the experiment. BD, Bulk Density; TC, total carbon; TN, total nitrogen; TK, total potassium and $\mathrm{TP}$, total phosphorus; \pm S.E. ( \pm standard error). Data comes from our previous studies [17].

\subsection{Experimental Design}

Five soil treatments were compared in the green roof, including natural soil (CK) and mixtures of local natural soil and $5 \%, 10 \%, 15 \%$ and $20 \%$ sludge biochar $(5 \% \mathrm{SB}, 10 \% \mathrm{SB}$, $15 \% \mathrm{SB}$ and $20 \% \mathrm{SB} ; v / v)$. The spatial distribution in this study was planned for five identical plots $(0.3 \mathrm{~m} \times 1 \mathrm{~m})$ with a soil depth of $25 \mathrm{~cm}$, and five types of soil treatments were evenly distributed in each plot (the location of each sample was random). This was equivalent to five repetitions per treatment. The vertical construction of the green roofs contained a waterproof membrane, drainage layer, filter layer and soil and plant layer, as in standard green roofs, and was managed as described by Luo et al. [18]. During the experiment, each plot randomly exchanged position every other month.

\subsection{Sampling Procedure and Determine Property}

Three sampling points were established randomly in every treatment. Destructive sampling was performed every 30 days. The sampling depth of the soil was $25 \mathrm{~cm}$. A total of 180 soil samples and plant samples were collected: (1) The soil samples were gently dug out with wooden shovels, mixed and impurities removed, then divided into two parts after being passed through a 2-mm-mesh sieve. Some were kept fresh for microbial extraction, and the rest were dried $\left(60^{\circ} \mathrm{C}, 72 \mathrm{~h}\right)$ to determine the soil $\mathrm{pH}$ and basic physicochemical properties. (2) Plant samples were gently removed from the soil by tweezers and cleaned. The plant samples were removed after gently stripping the soil with forceps. The plant samples were dried at $75^{\circ} \mathrm{C}$ for over $48 \mathrm{~h}$ and the biomass measured (dry weight). The ovendried samples were ground using stainless-steel grinders and sieved with a 100-mesh sieve for TOC measurements (Multi C/N 2100 and HT 1300, Jena, Thuringia, Germany). The pore structure characteristics of the biochar were analyzed with a Scanning Electron Microscope (Su8020, Hitachi, Tokyo, Japan) and BET surface area (ASAP 3020, Micromeritics Instrument Corporation, Norcross, GA, USA).

We measured the dry bulk density (DBD), soil porosity (SP) and water-holding capacity (WHC) as described by Handreck and Black [34]. Each sample $(600 \mathrm{~mL})$ was soaked in water for $30 \mathrm{~min}$, then drained for $5 \mathrm{~min}$. This cycle was then repeated three times. The soil bulk density and soil dry bulk density were determined by the ring knife method. The $\mathrm{BD}$ and $\mathrm{DBD}$ were determined by dividing the weight of the saturated soil and dry soil $\left(110{ }^{\circ} \mathrm{C}, 24 \mathrm{~h}\right)$ by their volumes [2]. SP (\%) was determined by one minus the ratio of the volume weight and initial weight, then multiplied by 100 . The difference was determined between the soil weight at the sample capacity and dry weight, divided by dry weight, and then multiplied by 100 represent WHC (\%). The soil nutrient concentrations in each sample included the total carbon (TC) measured by the Walkley-Black procedure [35]. Total nitrogen (TN) and available nitrogen (AN) were measured using the semi-Kjeldahl method [36]. Total phosphorus (TP) and total potassium (TK) were extracted from soil samples by perchloric acid digestion $(70 \%, 0.5 \mathrm{~mL})$ and sulfuric acid $(70 \%, 8 \mathrm{~mL})$ in an ETHOSA microwave digester (Milestone, Milan, Italy). The available phosphorus (AP) was extracted by the Olsen-P extraction [37], available potassium (AK) was extracted by $\mathrm{NH}_{4} \mathrm{Oac}, \mathrm{P}$ was determined by the molybdenum antimony anti-colorimetric method [37] and $\mathrm{K}$ was determined by the flame photometry method [38]. The soil and biochar cation exchange 
capacity (CEC) was measured according to the description of Mitchell and Huluka [39]. The temperature and moisture of the soil were monitored at a depth of $15 \mathrm{~cm}$. According to the changes of the environment temperature, the soil temperature was monitored for 5 days at 10:00 a.m. in the summer (from July to August) to monitor the soil water under the highest soil temperature. A portable $\mathrm{pH}$ meter (IQ 150, CO, USA) was used to measure the $\mathrm{pH}$.

The soil microbial community (Margalef's richness index and Shannon's diversity index) was assessed by an analysis of the phospholipid fatty acids (PLFAs), which were extracted in triplicate from each soil sample. The fresh dry soil samples of $8 \mathrm{~g}\left(-70^{\circ} \mathrm{C}\right)$ were extracted, and the phospholipid fatty acids were extracted with a modified Bligh-Dyer extract [40]. After the activated silica gel $\left(100^{\circ} \mathrm{C}, 1 \mathrm{~h}\right)$ was separated, $10 \mathrm{~mL}$ of chloroform, acetone and methanol were added, respectively. The methanol phase was collected as the extracted phospholipid fatty acid. The methyl esterification of the phospholipid fatty acid and then PLFA were analyzed using a HP6890 gas chromatograph coupled to a HP5973 mass selective detector (GC-MS, Agilent, Santa Clara, CA, USA), and the abundance in the microbial group was determined according to Chen et al. [41].

\subsection{Statistical Analysis}

ANOVA was used to determine the effects of the rate of biochar addition on the soil physical, chemical and biological properties and plant biomass. The $p$-value was significant under 0.05 . A linear regression analysis was used to determine the impact of the soil nutrients on the diversity of the soil microbial communities. The regression analysis results were indicated by $R^{2}\left(R^{2}>0.6\right.$ indicated an explanatory value). Meanwhile, the homogeneity of the variance and normal distribution of the samples were checked before the ANOVA analysis.

The generalized canonical discriminant and correlation analyses (gCCA) with the linear model were used to visualize the relationships between the soil properties and biological characters (soil microbial biomass, diversity, richness and plant biomass) on the green roof. The gCCA was performed under the candisc package [42]. Structural equation modeling (SEM) was used to analyze the responses of the biochar to the rooftop microbes and plants. Four paths were hypothesized to explain the impact of biochar on the rooftop plants. The factors of SEM were divided into the exogenous variable (biochar); soil property factors (temperature, moisture and soil porosity, soil TC, AN, AP, AK and dry bulk density); soil microbial factors (microbial biomass, diversity index, richness index and eukaryote biomass) and organic matter input factors (plant biomass and plant carbon content). Most of the variables or categories examined in the experiment were correlated with each other, making these datasets appropriate for the SEM analysis. The SEM model was implemented in the lavaan package [43]. All variables were transformed to their natural logarithms to mitigate the departure from normality and linearity. The nonparametric Bollen-Stine bootstrapping estimations were used to address the potential problems of nonlinearity and remaining univariate non-normality after transformations, which increased the credibility of our SEMs [43]. The results of the ANOVAs informed the initial path analysis model, and a high $p$-value associated with a $\chi^{2}$ test indicated a good fit of the model to the data, i.e., no significant discrepancies. The model fit was determined via $\chi^{2}$ tests and Akaike information criterion (AIC). An adjusted Goodness-of-fit index (AGFI > 0.9) indicated that the model had a high degree of adaptation [41]. All statistics and figures were produced with R software version 3.0.1.

\section{Results}

\subsection{Biochar Adjusted Physical and Chemical Properties of Roof Soil}

Scanning electron microscopy showed that biochar had a very significant pore structure and relatively uniform pore size distribution (Figure 1). The BET surface area of the biochar was $24.04 \mathrm{~m}^{2} \cdot \mathrm{g}^{-1}$. The physical properties (DBD, WHC and SP) of the soil were significantly related to the biochar $\left(\mathrm{R}^{2}=0.815-0.970, p<0.05\right)$. Compared to the CK treat- 
ment, the biochar significantly increased the soil porosity (5.3-9.3\%) and water-holding capacity (14.0-37.2\%) and, at the same time, decreased the dry bulk density (3.9-10.8\%). The biochar increased the soil water and soil temperature in the spring. However, in the summer, the soil temperature decreased first and then increased as the biochar increased. The biochar increased the total soil nutrient content and adjusted soil $\mathrm{pH}\left(R^{2}=0.839-0.988\right.$, $p<0.03$; Table 2). Compared with other available nutrients, the content of the available nitrogen increased the most $(90.2 \%$, Table 2$)$.
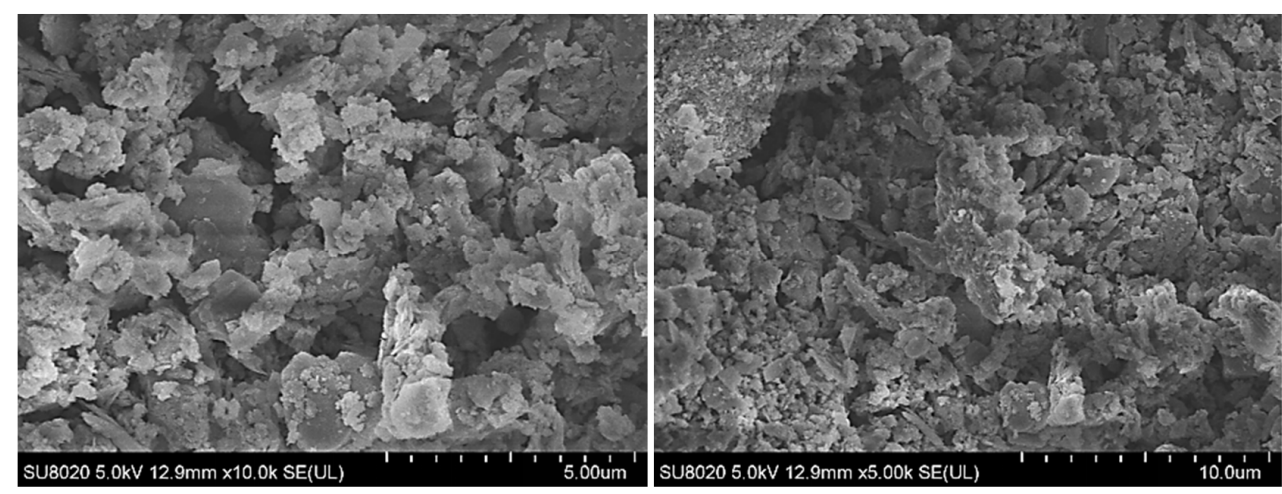

Figure 1. The scanning electron microscopy of the biochar $(5 \mu \mathrm{m}$ and $10 \mu \mathrm{m})$.

Table 2. The physicochemical properties of the green roof soil.

\begin{tabular}{|c|c|c|c|c|c|c|c|c|}
\hline Treatments & $\begin{array}{c}\text { DBD } \\
\left(\mathrm{kg} \mathrm{L}^{-1}\right)\end{array}$ & $\begin{array}{c}\text { WHC } \\
(\%)\end{array}$ & $\begin{array}{l}\text { SP } \\
(\%)\end{array}$ & $\mathrm{pH}$ & $\begin{array}{c}\mathrm{TC} \\
\left(\mathrm{g} \mathrm{kg}^{-1}\right)\end{array}$ & $\begin{array}{c}\mathrm{TN} \\
\left(\mathrm{g} \mathrm{kg}^{-1}\right)\end{array}$ & $\begin{array}{c}\mathrm{TP} \\
\left(\mathrm{g} \mathrm{kg}^{-1}\right)\end{array}$ & $\begin{array}{c}\text { TK } \\
\left(\mathrm{g} \mathrm{kg}^{-1}\right)\end{array}$ \\
\hline CK & $\begin{array}{c}1.02 \pm 0.02 \\
\mathrm{a}\end{array}$ & $\begin{array}{c}43.56 \pm 0.17 \\
\mathrm{e}\end{array}$ & $\begin{array}{c}58.32 \pm 0.06 \\
\mathrm{~d}\end{array}$ & $\begin{array}{c}8.17 \pm 0.03 \\
\mathrm{a}\end{array}$ & $\begin{array}{c}19.63 \pm 0.15 \\
\mathrm{e}\end{array}$ & $\begin{array}{c}1.38 \pm 0.03 \\
\mathrm{e}\end{array}$ & $\begin{array}{c}0.96 \pm 0.06 \\
\mathrm{c}\end{array}$ & $\begin{array}{c}1.15 \pm 0.06 \\
\mathrm{~d}\end{array}$ \\
\hline $5 \% \mathrm{SB}$ & $\begin{array}{c}0.98 \pm 0.03 \\
b\end{array}$ & $\begin{array}{c}49.66 \pm 0.12 \\
\mathrm{~d}\end{array}$ & $\begin{array}{c}61.38 \pm 0.05 \\
c\end{array}$ & $\begin{array}{c}7.67 \pm 0.02 \\
b\end{array}$ & $\begin{array}{c}24.57 \pm 0.08 \\
\mathrm{~d}\end{array}$ & $\begin{array}{c}1.76 \pm 0.01 \\
\mathrm{~d}\end{array}$ & $\begin{array}{c}1.02 \pm 0.03 \\
\mathrm{c}\end{array}$ & $\begin{array}{c}1.23 \pm 0.03 \\
\mathrm{~cd}\end{array}$ \\
\hline $10 \% \mathrm{SB}$ & $\begin{array}{c}0.95 \pm 0.02 \\
\text { bc }\end{array}$ & $\begin{array}{c}55.72 \pm 0.21 \\
\mathrm{c}\end{array}$ & $\begin{array}{c}62.77 \pm 0.08 \\
b\end{array}$ & $\begin{array}{c}7.32 \pm 0.01 \\
\mathrm{c}\end{array}$ & $\begin{array}{c}29.65 \pm 0.16 \\
c\end{array}$ & $\begin{array}{c}2.53 \pm 0.02 \\
c\end{array}$ & $\begin{array}{c}1.15 \pm 0.02 \\
\mathrm{~b}\end{array}$ & $\begin{array}{c}1.32 \pm 0.06 \\
\mathrm{bc}\end{array}$ \\
\hline $15 \% \mathrm{SB}$ & $\begin{array}{c}0.93 \pm 0.01 \\
\text { cd }\end{array}$ & $\begin{array}{c}57.23 \pm 0.18 \\
b\end{array}$ & $\begin{array}{c}63.63 \pm 0.12 \\
\mathrm{a}\end{array}$ & $\begin{array}{c}7.28 \pm 0.02 \\
\mathrm{~cd}\end{array}$ & $\begin{array}{c}28.99 \pm 0.12 \\
b\end{array}$ & $\begin{array}{c}2.75 \pm 0.05 \\
b\end{array}$ & $\begin{array}{c}1.21 \pm 0.03 \\
\mathrm{ab}\end{array}$ & $\begin{array}{c}1.39 \pm 0.07 \\
\mathrm{~b}\end{array}$ \\
\hline $20 \%$ SB & $\begin{array}{c}0.91 \pm 0.02 \\
\mathrm{~d}\end{array}$ & $\begin{array}{c}59.76 \pm 0.22 \\
a\end{array}$ & $\begin{array}{c}63.76 \pm 0.13 \\
\mathrm{a}\end{array}$ & $\begin{array}{c}7.25 \pm 0.03 \\
\mathrm{~d}\end{array}$ & $\begin{array}{c}31.16 \pm 0.11 \\
\mathrm{a}\end{array}$ & $\begin{array}{c}2.97 \pm 0.06 \\
\mathrm{a}\end{array}$ & $\begin{array}{c}1.23 \pm 0.01 \\
\mathrm{a}\end{array}$ & $\begin{array}{c}1.56 \pm 0.03 \\
\mathrm{a}\end{array}$ \\
\hline Treatments & $\begin{array}{c}\mathrm{AN} \\
\left(\mathrm{mg} \mathrm{kg}^{-1}\right)\end{array}$ & $\begin{array}{c}\mathrm{AP} \\
\left(\mathrm{mg} \mathrm{kg}^{-1}\right)\end{array}$ & $\begin{array}{c}\mathrm{AK} \\
\left(\mathrm{mg} \mathrm{kg}^{-1}\right)\end{array}$ & $\begin{array}{c}\text { CEC } \\
\left(\operatorname{coml~kg}^{-1}\right)\end{array}$ & $\begin{array}{c}\text { Soil Water } \\
(\%)\end{array}$ & $\begin{array}{c}\text { Soil } \\
\text { Temperature } \\
\left({ }^{\circ} \mathrm{C}\right)\end{array}$ & $\begin{array}{c}\text { SWM } \\
(\%)\end{array}$ & $\begin{array}{l}\text { SMT } \\
\left({ }^{\circ} \mathrm{C}\right)\end{array}$ \\
\hline CK & $\begin{array}{c}9.32 \pm 0.15 \\
\mathrm{e}\end{array}$ & $\begin{array}{c}6.43 \pm 0.06 \\
\mathrm{e}\end{array}$ & $\begin{array}{c}10.12 \pm 0.16 \\
\mathrm{e}\end{array}$ & $\begin{array}{c}9.17 \pm 0.66 \\
\mathrm{~d}\end{array}$ & $\begin{array}{c}31.63 \pm 0.32 \\
\mathrm{~d}\end{array}$ & $\begin{array}{c}11.62 \pm 0.12 \\
\mathrm{e}\end{array}$ & $\begin{array}{c}46.6 \pm 0.26 \\
a\end{array}$ & $\begin{array}{c}21.5 \pm 0.25 \\
\mathrm{e}\end{array}$ \\
\hline $5 \%$ SB & $\begin{array}{c}12.11 \pm 0.08 \\
\mathrm{~d}\end{array}$ & $\begin{array}{c}6.83 \pm 0.03 \\
\mathrm{~d}\end{array}$ & $\begin{array}{c}10.82 \pm 0.11 \\
\mathrm{~d}\end{array}$ & $\begin{array}{c}12.66 \pm 1.06 \\
c\end{array}$ & $\begin{array}{c}33.71 \pm 0.21 \\
c\end{array}$ & $\begin{array}{c}12.15 \pm 0.15 \\
\mathrm{~d}\end{array}$ & $\begin{array}{c}45.3 \pm 0.17 \\
\mathrm{c}\end{array}$ & $\begin{array}{c}23.8 \pm 0.19 \\
\mathrm{~d}\end{array}$ \\
\hline $10 \% \mathrm{SB}$ & $\begin{array}{c}13.23 \pm 0.16 \\
c\end{array}$ & $\begin{array}{c}7.71 \pm 0.08 \\
\mathrm{c}\end{array}$ & $\begin{array}{c}11.62 \pm 0.09 \\
c\end{array}$ & $\begin{array}{c}14.26 \pm 1.02 \\
b\end{array}$ & $\begin{array}{c}37.96 \pm 0.63 \\
b\end{array}$ & $\begin{array}{c}13.72 \pm 0.29 \\
c\end{array}$ & $\begin{array}{c}41.3 \pm 0.11 \\
\mathrm{e}\end{array}$ & $\begin{array}{c}30.7 \pm 0.16 \\
a\end{array}$ \\
\hline $15 \%$ SB & $\begin{array}{c}15.65 \pm 0.06 \\
b\end{array}$ & $8.11 \pm 0.11$ & $\begin{array}{c}12.23 \pm 0.12 \\
b\end{array}$ & $\begin{array}{c}15.57 \pm 0.95 \\
\mathrm{ab}\end{array}$ & $\begin{array}{c}38.65 \pm 0.56 \\
b\end{array}$ & $\begin{array}{c}15.23 \pm 0.18 \\
b\end{array}$ & $\begin{array}{c}43.8 \pm 0.16 \\
\mathrm{~d}\end{array}$ & $29.6 \pm 0.22$ \\
\hline $20 \%$ SB & $\begin{array}{c}17.72 \pm 0.06 \\
\mathrm{a}\end{array}$ & $\begin{array}{c}8.26 \pm 0.09 \\
a\end{array}$ & $\begin{array}{c}13.73 \pm 0.22 \\
\mathrm{a}\end{array}$ & $\begin{array}{c}16.13 \pm 0.58 \\
\mathrm{a}\end{array}$ & $\begin{array}{c}49.52 \pm 0.37 \\
\mathrm{a}\end{array}$ & $\begin{array}{c}16.86 \pm 0.26 \\
a\end{array}$ & $44.9 \pm 0.23$ & $\begin{array}{c}27.7 \pm 0.32 \\
c\end{array}$ \\
\hline
\end{tabular}

Notes. SB is soil and biochar mixed with different rates, DBD = dry bulk density, WHC = water-holding capacity, SP = soil porosity, $\mathrm{TC}=$ total carbon, $\mathrm{TN}=$ total nitrogen, $\mathrm{TP}=$ total phosphorus, $\mathrm{TK}=$ total potassium, $\mathrm{AN}=$ available nitrogen, $\mathrm{AP}=$ available phosphorus, $\mathrm{AK}=$ available potassium, CEC = cation exchange capacity, SWM = soil water at the maximum soil temperature in the summer and $\mathrm{SMT}=$ maximum soil temperature in the summer; \pm S.E. ( \pm standard error). All data with different letters indicate the significant differences between them.

\subsection{Biochar Improved the Biological Characteristics of the Green Roof}

A biochar addition can significantly increase the roof microbial biomass and plant biomass, and discriminant and further regression analyses showed a high correlation between the microbial biomass, plant biomass and soil properties (Figures 2 and 3). The highest biomass and carbon content of the plants were found in the $10 \% \mathrm{SB}\left(15.48 \mathrm{~g} \mathrm{plant}^{-1}\right.$ and $31.27 \mathrm{mg} \mathrm{kg}^{-1}$ ), 15\%SB (15.92 $\mathrm{g} \mathrm{plant}^{-1}$ and $32.77 \mathrm{mg} \mathrm{kg}^{-1}$ ) and 20\%SB (15.67 $\mathrm{g} \mathrm{plant}^{-1}$ 
and $30.41 \mathrm{mg} \mathrm{kg}^{-1}$ ) treatments (Figure 2A,B). After the biochar addition, the total soil microbial biomass and total eukaryote biomass maximum increased by $75.3 \%(15 \% \mathrm{SB})$ and $269.1 \%(15 \% \mathrm{SB})$, respectively (Figure 2C,F).
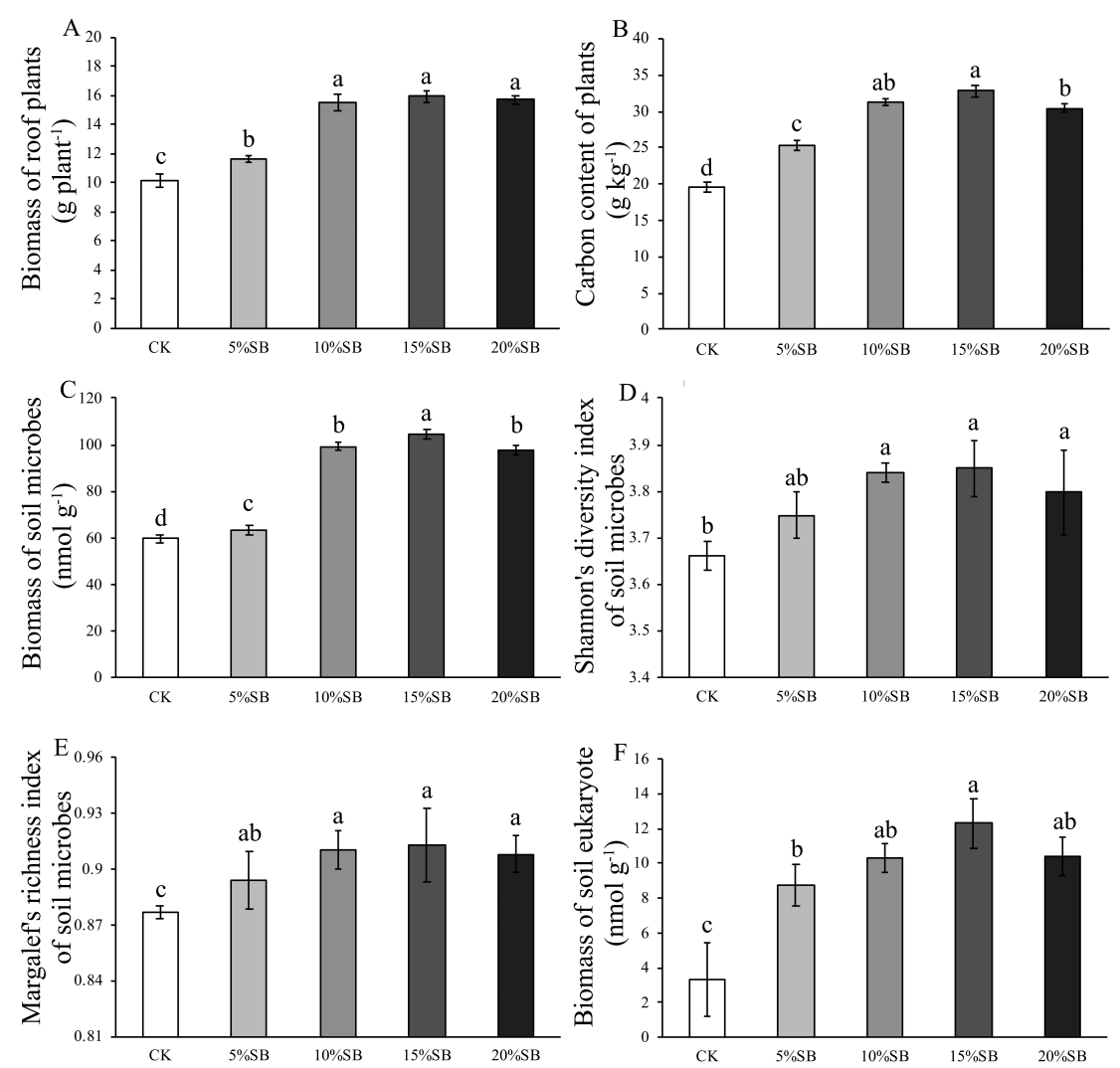

Figure 2. Biological indicators of green roofs. (A) Biomass of roof plants. (B) Carbon content of plants. (C) Biomass of roof soil microbes. (D) Shannon's diversity index of soil microbes. (E) Margalef's richness index of soil microbes. (F) Biomass of roof soil eukaryotes. The significant differences $(p<0.005)$ between biochar treatments are shown as different lowercase letters on the top of each column. Error bars represent standard errors $(n=3)$.

Margalef's richness index and Shannon's diversity index increased when the biochar was added (Figure 2D,E), and the soil available nutrients had a positive correlation with the plant and soil microbial diversity $\left(R^{2}=0.359-0.951, p<0.001\right.$; Figure 3$)$. The soil nutrients promoted the diversity of the microbial community in the biochar treatment compared with the CK treatment (Figure 4). The diversity of the microbial community had the highest correlation with the TP $\left(\mathrm{R}^{2}=0.7544, p<0.001\right.$; Figure $\left.4 \mathrm{C}\right)$ and TC $\left(\mathrm{R}^{2}=0.7174, p<0.001\right.$; Figure 4A).

SEM showed that the effect of biochar on roof plants and microbes was achieved by adjusting the soil properties of the roof soil. The path coefficient of biochar to the soil properties (soil porosity, water and nutrients) was 0.89 , and the degree of interpretation was 0.78 , which showed that biochar had a significant effect on the soil properties. Meanwhile, the path coefficients of biochar to the soil microorganisms and plants were 0.22 and 0.17 , which means the direct influence of biochar on the soil properties was stronger than that of biochar on the soil microbes and plants. The significance of the path coefficients showed that biochar has a direct effect on the microbe $(p=0.03)$ but no direct impact on the plants $(p=0.07)$ (Figure 5). A $\chi^{2}$ test indicated that our hypothesized path analysis model could not be rejected as a potential explanation of the observed covariance matrix $\left(\chi^{2}=431.278\right.$, $p=0.052, \mathrm{AIC}=519.278$ and $\mathrm{AGFI}=0.903$ ). 


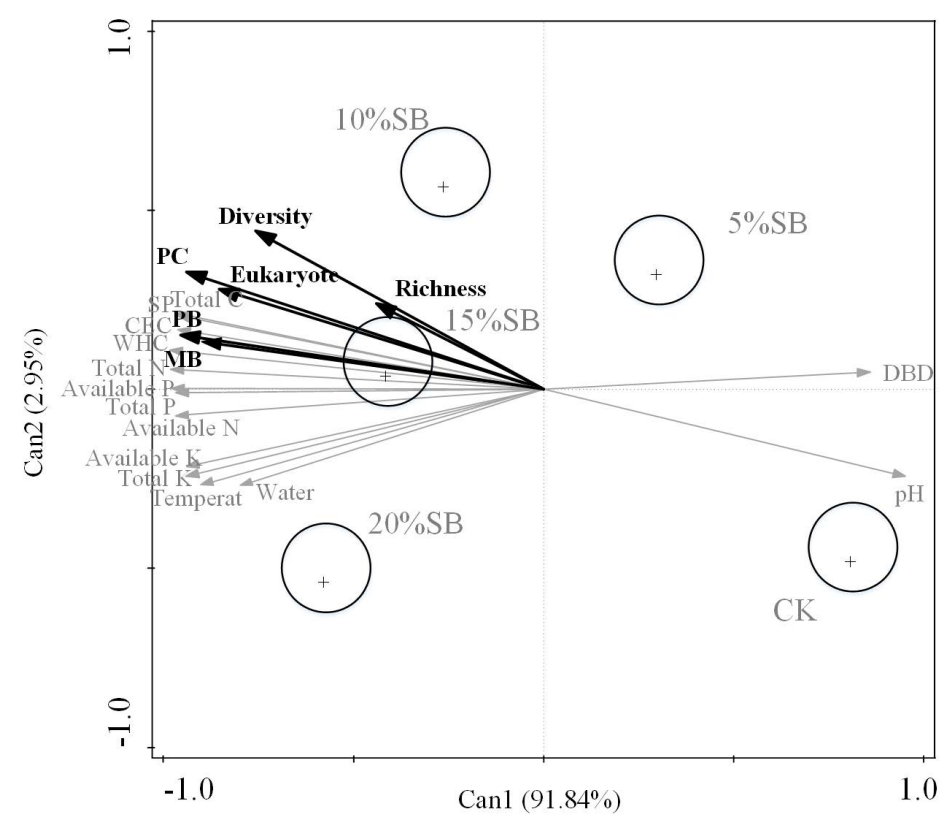

Figure 3. Generalized canonical discriminant and analysis (gCCA) showing the relationships among the soil physical properties, soil nutrients and abundance-based indicators of the green roof biology. Abundance-based indicators are the total microbial abundance, Shannon's diversity index, Margalef's richness index, total plants and eukaryotes. The circles represent the $95 \%$ confidence intervals around the site treatment mean. Abbreviations are expressed: $\mathrm{DBD}=$ dry bulk density, $\mathrm{WHC}=$ water-holding capacity, $\mathrm{SP}=$ soil porosity, Total $\mathrm{C}=$ total carbon, Total $\mathrm{N}=$ total nitrogen, Total $\mathrm{P}=$ total phosphorus, Total $\mathrm{K}=$ total potassium, Available $\mathrm{N}$ = available nitrogen, Available $\mathrm{P}=$ available phosphorus, Available $\mathrm{K}=$ available potassium, $\mathrm{CEC}=$ cation exchange capacity, $\mathrm{PB}=$ plant biomass, $\mathrm{PC}=$ plant carbon and $\mathrm{MB}=$ microbial biomass. Biochar addition treatments were: $\mathrm{CK}$, no biochar; $5 \% \mathrm{SB}, 5 \%$ biochar; $10 \%$ SB, $10 \%$ biochar; $15 \%$ SB, $15 \%$ biochar and 20\%SB, $20 \%$ biochar.
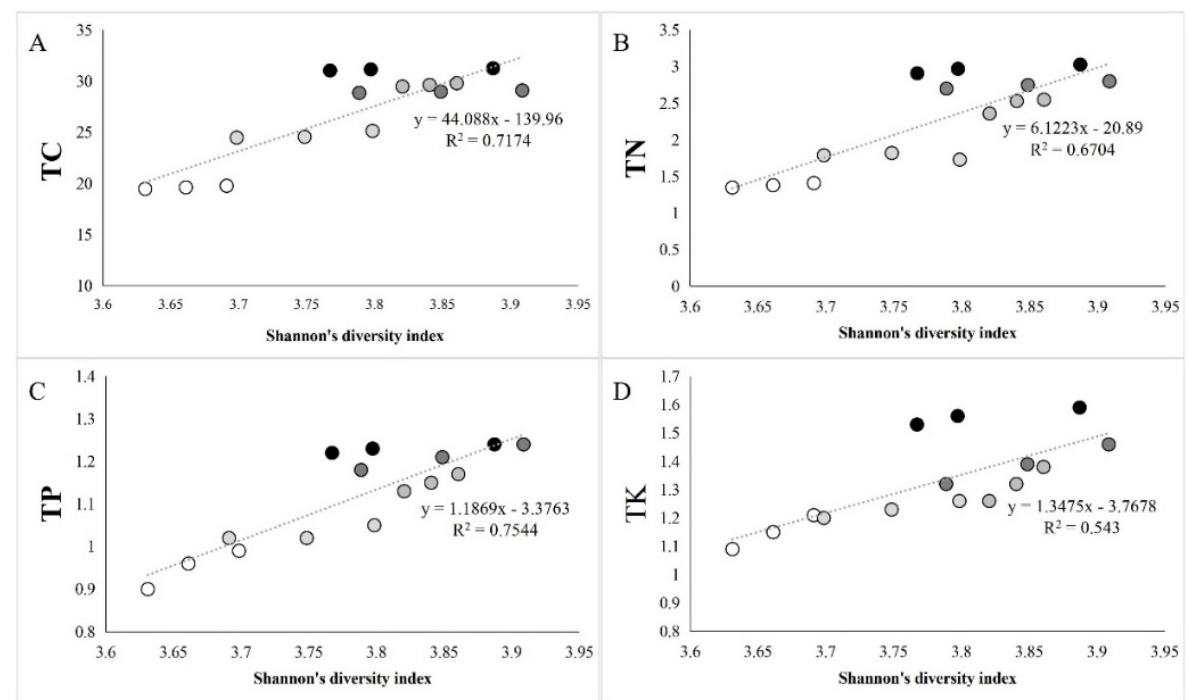

Figure 4. Relationships between the soil nutrients and the diversity index of the microbe in the roof ecosystem. R-squared $\left(R^{2}\right)$ and $p$-values were estimated from a linear regression model, and the best-fit line is shown on the graph. Biochar treatments were: $\mathrm{CK}$, no biochar $(\mathrm{O}) ; 5 \% \mathrm{SB}$, soil and 5\% biochar $(\mathrm{O}) ; 10 \% \mathrm{SB}$, soil and 10\% biochar $(\mathrm{O}) ; 15 \% \mathrm{SB}$, soil and $15 \%$ biochar $(\mathrm{O})$ and $20 \% \mathrm{SB}$, soil and $20 \%$ biochar ( ). (A-D) Total carbon $\left(\mathrm{g} \mathrm{kg}^{-1}\right)$, total nitrogen $\left(\mathrm{g} \mathrm{kg}^{-1}\right)$, total phosphorus $\left(\mathrm{g} \mathrm{kg}^{-1}\right)$ and total potassium $\left(\mathrm{g} \mathrm{kg}^{-1}\right)$ of the roof soil, respectively. 


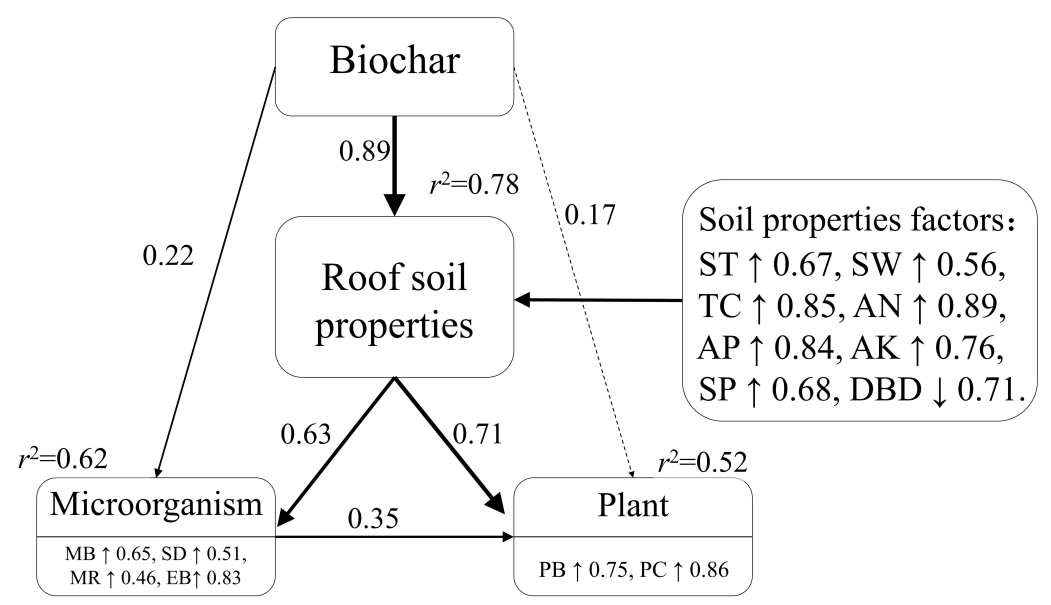

Figure 5. SEM analysis of the biochar effects on green roof microorganisms and plants. Square boxes indicate the variables included in the model: $\mathrm{SP}=$ soil porosity, $\mathrm{SAK}=$ soil available potassium, $\mathrm{MB}=$ microbial biomass, $\mathrm{SD}=$ diversity index, $\mathrm{MR}=$ richness index, $\mathrm{EB}=$ eukaryote biomass, $\mathrm{PB}=$ plant biomass and $\mathrm{PC}=$ plant carbon content. For ST, SW, TC, AN, AP and DBD, see Table 2. The symbols " $\uparrow$ " and " $\downarrow$ " indicate a significant increase or decrease, respectively, in response to the biochar addition. The number indicates the response to the addition of the additives. Solid and dashed arrows indicate significant $(p<0.05)$ and nonsignificant effects $(p>0.05)$, respectively. $r^{2}$ values associated with the response variables indicate the proportion of the variations explained by the relationships with other variables. The values associated with the solid arrows represent standardized path coefficients.

\section{Discussion}

\subsection{Influence Mechanism of Biochar on Physical Properties of the Roof Soil}

The porous structure of the biochar increased the porosity of the roof soil, thus resulting in the increase of the soil moisture and the soil temperature regulation. It led to the survival and reproduction of soil microorganisms on the roof (Table 2 and Figures 2, 3 and 5). The biochar addition reduced the bulk density of the roof soil because of the loose and porous structure of the biochar [44]. It made biochar have the potential to act as a green roof substrate amendment. Since the building structure limited the bearing capacity of the roof, the light but large-volume substrate will be a good choice for green roofs [4]. The addition of biochar can reduce the weight of soil at the same volume via reducing the density. That means that, with the same building bearing capacity, soil with biochar has a bigger volume in comparison with pure soil. Therefore, it provides more room on roofs for microbes and plants, and the range of which vegetation species can grow on roofs is enlarged $[9,18]$. In addition, biochar can increase the water-holding capacity of roof soils, which means that biochar soil can retain more rainwater and nutrients for plants, microbes, etc. (Table 2). Biochar's absorption capacity can reduce the roof soil loss caused by the water flow, which can improve the management and maintenance of green roofs [17]. This can also make green roofs have longer ecological benefits. Moreover, a biochar addition makes the soil become a more humid and with a medium porosity, which improves the evaporation and, consequently, adjusts the soil moisture and temperature (Table 2 and Figure 1). Summarily, a biochar addition provides a guarantee for the survival of microbes and plants on the roof in the summer.

\subsection{Influence Mechanism of Biochar on Nutrients of the Roof Soil}

On the roof, the harsh environment and climate make the soil lose nutrients severely [5], such as the $\mathrm{N}$ of roof soil decomposing and emitting ammonia gas at high temperatures. The runoff produced by a rainstorm takes away a lot of soluble nutrients [45]. In the study, the nutrients of the roof soil increased significantly when biochar was added (Table 2). Compared with the CK, the soil available nutrients increased by $28.5-90.2 \%$, and the total 
nutrients increased by 28.1-115.2\%. It may be because biochar has high porous properties and strong adsorption [46], which can increase the retention of N, P and K even in rainwater, reducing the loss of soil nutrients [47]. On the other hand, biochar can neutralize the soil $\mathrm{pH}$ (Table 2) and promote the formation of soil organic matter to maintain the soil quality and increase the soil fertility for microbes and plant growth [48]. In addition, roof soils with biochar can effectively alleviate the nutrient pollution problem and potential water pollution [47], which means that biochar performs better than traditional roof soil materials.

\subsection{Effect of Biochar on Biological Traits of the Roof Soil}

Compared with the CK treatment, the biochar addition significantly increased the microbial biomass and diversity (Figure 2). Meanwhile, the microbial diversity and soil nutrients were correlated $\left(\mathrm{R}^{2}=0.359-0.717, p<0.05\right)$ (Figure 3$)$. The results of the SEM also showed that biochar has a direct effect on the increase of the microbial biomass in roof soil. This may be largely due to two reasons. Firstly, it is biochar that adsorbs microbes into their pores, which provides good protection and a habitat environment for microorganisms [17], and the other is that the soil nutrients were increased by the biochar addition, which accelerated the microbial reproduction, especially the increase of roof soil P and $\mathrm{N}$ (Figure 4); this gave the soil microbes a good energy source to produce essential biological molecules [49]. In addition, there are also studies showing that biochar itself contains partially unstable components [50,51]. It can be used by specific microorganisms [52], and this may also be one factor directly impacting roof microbes.

In this study, biochar significantly increased the biomass of the plants (Figure 2), and the plant biomass had a high correlation with the soil CEC, TN and WHC $\left(\mathrm{R}^{2}=0.853-0.951\right.$, $p<0.03$, Figure 3). This may be due to the functional groups on the surface of the biochar making it have a strong adsorption capacity. Adding it to the soil can adsorb a large number of mineral elements and significantly improve the CEC level of the soil, thereby improving the soil nutrient content and plant nutrient utilization [53]. The addition of biochar can bring more nutrients to plants, e.g., the effective nutrients that biochar carries and the retention of soluble nutrients in rainwater by adsorption [54]. Furthermore, a biochar addition increasing the WHC can effectively ensure the water content of the roof soil, which is beneficial to protecting plants from drought stress. There are also reports showing that biochar promotes crop growth by improving soil microorganism inhabitations $[55,56]$. This also confirms the improvement of microbes on the plants in the SEM results (Figure 5).

Biochar can promote eukaryotes growth, because larger microbial and plant biomass in biochar roof ecosystems provided more trophic resources (Figure 2). However, the microbial diversity and richness of the roof soil increased first, but then decreased when the biochar application increased. An explanation may be that a larger amount of biochar ( $>20 \%$ ) accelerates the soil nutrient loss and increases the roof soil temperature and water evaporation in extreme climates (especially in the summer) [29], which makes the roof soil environment worse. Therefore, in the research, adding 10-15\% of biochar is the best alternative to maintaining the growth of microorganisms and plants.

The path coefficient of the structural equation model showed that biochar influenced many ecological components of the roof. The effects of a biochar addition on the properties of roof soils are an important process affecting plants and microbes [2,57]. As the main body achieving the roof ecological benefits and the index of the reaction ecosystem, plant and soil microbes can effectively demonstrate the advantages and disadvantages of the roof soil ecosystem.

\section{Conclusions}

This research showed that the microbial and plant biomass increased significantly when biochar was added properly, which indicated that biochar could effectively promote the stability of roof ecosystems and improve the ecological benefits of green roofs. In addition, a biochar addition in roof ecosystems causes an environmental change in the roof biology. It is mainly because of its effects on the soil properties like the soil porosity, water 
content and soil nutrients, regulating the roof soil temperature. Thereby, a biochar addition could promote soil microorganisms and plant growth, which enable biochar to become a good roof soil amendment.

Author Contributions: Conceptualization, H.C.; data curation, H.C., X.D. and M.N.; methodology, X.D. and M.L.; writing-original draft, H.C. and C.L. and writing-review and editing, W.Q. All authors have read and agreed to the published version of the manuscript.

Funding: The work was supported by the Natural Science Foundation of China Project (No. 42007105) and Scientific Research Funds of Nanjing University of Science and Technology (AZ89991/197).

Institutional Review Board Statement: Not applicable.

Informed Consent Statement: Not applicable.

Data Availability Statement: Not applicable.

Acknowledgments: The authors are thankful to the School of Infrastructure, College of Resources and Environmental Sciences of Nanjing Agricultural University, China for providing the facilities in which we conducted this research.

Conflicts of Interest: The authors declare no conflict of interest.

\section{References}

1. Benjamin, T. City of Atlanta green roof demonstration project. In Proceedings of the Chicago: First Annual Greening Rooftops for Sustainable Communities Conference, Awards and Trade Show, Chicago, IL, USA, 29-30 May 2003; pp. 29-30.

2. Cao, C.T.; Farrell, C.; Kristiansen, P.E.; Rayner, J.P. Biochar makes green roof soils lighter and improves water supply to plants. Ecol. Eng. 2014, 71, 368-374. [CrossRef]

3. Dvorak, B.; Volder, A. Green roof vegetation for North American ecoregions: A literature review. Landsc. Urban Plan. 2010, 96, 197-213. [CrossRef]

4. Getter, K.L.; Rowe, D.B. Substrate depth influences Sedum plant community on a green roof. HortScience 2009, 44, 401-407. [CrossRef]

5. Oberndorfer, E.; Lundholm, J.; Bass, B.; Coffman, R.R.; Doshi, H.; Dunnett, N.; Gaffin, S.; Köhler, M.; Liu, K.; Rowe, A.B. Green roofs as urban ecosystems: Ecological structures, functions, and services. Bioscience 2007, 57, 823-833. [CrossRef]

6. Williams, N.S.; Rayner, J.P.; Raynor, K.J. Green roofs for a wide brown land: Opportunities and barriers for rooftop greening in Australia. Urban For. Urban Green. 2010, 9, 245-251. [CrossRef]

7. Yang, J.; Yu, Q.; Gong, P. Quantifying air pollution removal by green roofs in Chicago. Atmos. Environ. 2008, $42,7266-7273$. [CrossRef]

8. Brenneisen, S. The benefits of biodiversity from green roofs: Key design consequences. In Proceedings of the 1st North American Green Roof Conference, Chicago, IL, USA, 29-30 May 2003; pp. 323-329. Available online: https://www.researchgate.net/ publication/313050350 (accessed on 15 May 2021).

9. Molineux, C.J.; Gange, A.C.; Connop, S.P.; Newport, D.J. Using recycled aggregates in green roof substrates for plant diversity. Ecol. Eng. 2015, 82, 596-604. [CrossRef]

10. Macivor, J.S.; Lundholm, J. Performance evaluation of native plants suited to extensive green roof conditions in a maritime climate. Ecol. Eng. 2011, 37, 407-417. [CrossRef]

11. Molineux, C.J.; Fentiman, C.H.; Gange, A.C. Characterising alternative recycled waste materials for use as green roof growing media in the U.K. Ecol. Eng. 2009, 35, 1507-1513. [CrossRef]

12. Molineux, C.J.; Gange, A.C.; Newport, D.J. Using soil microbial inoculations to enhance substrate performance on extensive green roofs. Sci. Total Environ. 2017, 580, 846-856. [CrossRef]

13. Wolf, D.; Lundholm, J.T. Water uptake in green roof microcosms: Effects of species and water availability. Ecol. Eng. 2008, 33, 179-186. [CrossRef]

14. Dunnett, N.; Kingsbury, N. Planting Green Roofs and Living Walls, 2nd ed.; Timber Press: Portland, OR, USA, 2010.

15. Molineux, C.J.; Connop, S.P.; Gange, A.C. Manipulating soil microbial communities in extensive green roof substrates. Sci. Total Environ. 2014, 493, 632-638. [CrossRef] [PubMed]

16. Rowe, D.B.; Getter, K.L.; Durhman, A.K. Effect of green roof media depth on crassulacean plant succession over seven years. Landsc. Urban Plan. 2012, 104. [CrossRef]

17. Chen, H.; Ma, J.; Wei, J.; Gong, X.; Yu, X.; Guo, H.; Zhao, Y. Biochar increases plant growth and alters microbial communities via regulating the moisture and temperature of green roof substrates. Sci. Total Environ. 2018, 635, 333-342. [CrossRef]

18. Luo, H.; Liu, X.; Anderson, B.C.; Zhang, K.; Li, X.; Huang, B.; Chen, F. Carbon sequestration potential of green roofs using mixed-sewage-sludge soil in Chengdu World Modern Garden City. Ecol. Indic. 2015, 49, 247-259. [CrossRef]

19. Chen, H.; Ma, J.; Wang, X.; Xu, P.; Zheng, S.; Zhao, Y. Effects of Biochar and Sludge on Carbon Storage of Urban Green Roofs. Forests 2018, 9, 413. [CrossRef] 
20. Ahmad, M.; Rajapaksha, A.U.; Lim, J.E.; Zhang, M.; Ok, Y.S. Biochar as a sorbent for contaminant management in soil and water: A review. Chemosphere 2013, 99, 19-33. [CrossRef] [PubMed]

21. Chen, H.; Zhang, J.; Tang, L.; Su, M.; Tian, D.; Zhang, L. Enhanced pb immobilization via the combination of biochar and phosphate solubilizing bacteria. Environ. Int. 2019, 127, 395-401. [CrossRef] [PubMed]

22. Chen, H.; Tang, L.; Wang, Z.; Su, M.; Li, Z. Evaluating the protection of bacteria from extreme cd (ii) stress by p-enriched biochar. Environ. Pollut. 2010, 263. [CrossRef]

23. Kimetu, J.M.; Lehmann, J. Stability and stabilisation of biochar and green manure in soil with different organic carbon contents. Soil Res. 2010, 48, 577-585. [CrossRef]

24. Shinogi, Y.; Kanri, Y. Pyrolysis of plant, animal and human waste: Physical and chemical characterization of the pyrolytic products. Bioresour. Technol. 2003, 90, 241-247. [CrossRef]

25. Lehmann, J.; da Silva, J.P., Jr.; Steiner, C.; Nehls, T.; Zech, W.; Glaseret, B.; Jindo, K. Nutrient availability and leaching in an archaeological Anthrosol and a Ferralsol of the Central Amazon basin: Fertilizer, manure and charcoal amendments. Plant Soil 2003, 249, 343-357. [CrossRef]

26. Biederman, L.A.; Harpole, W.S. Biochar and its effects on plant productivity and nutrient cycling: A meta-analysis. GCB Bioenergy 2013, 5, 202-214. [CrossRef]

27. Liang, Y.; Cao, X.D.; Zhao, L.; Xu, X.Y.; Harris, W. Phosphorus release from dairy manure, the manure-derived biochar, and their amended soil: Effects of phosphorus nature and soil property. J. Environ. Qual. 2017, 43, 1504. [CrossRef] [PubMed]

28. Piscitelli, L.; Rivier, P.A.; Mondelli, D.; Miano, T.; Joner, E.J. Assessment of addition of biochar to filtering mixtures for potential water pollutant removal. Environ. Sci. Pollut. Res. 2014, 25, 2167-2174. [CrossRef] [PubMed]

29. Jindo, K.; Sánchez-Monedero, M.A.; Hernández, T.; García, C.; Furukawa, T.; Matsumoto, K.; Sonoki, T.; Bastida, F. Biochar influences the microbial community structure during manure composting with agricultural wastes. Sci. Total Environ. 2012, 416, 476-481. [CrossRef] [PubMed]

30. Zhu, X.M.; Chen, B.L.; Zhu, L.Z.; Xing, B.S. Effects and mechanisms of biochar-microbe interactions in soil improvement and pollution remediation: A review. Environ. Pollut. 2017, 227, 98-115. [CrossRef]

31. Coomes, O.T.; Miltner, B.C. Indigenous charcoal and biochar production: Potential for soil improvement under shifting cultivation systems. Land Degrad. Dev. 2017, 28, 811-821. [CrossRef]

32. FLL. Guidelines for the Planning, Execution and Upkeep of Green-Roof Sites (English Version); Forschungsgesellschaft Landschaftsentwicklung Landschaftsbau e.V.: Troisdorf, Germany, 2002; pp. 1-97.

33. AQSIQ (General Administration of Quality Supervision, Inspection and Quarantine of the China); SAC (Standardization Administration of China). The Disposal of Sludge from Municipal Wastewater Treatment Plant-The Quality of Sludge Used in Gardens or Parks (GB/T 23486-2009). 2009; pp. 1-8. Available online: http://www.jianbiaoku.com/webarbs/book/58530/1100 138.shtml (accessed on 15 May 2021).

34. Handreck, K.; Black, N.; Handreck, K.; Black, N. Growing Media for Ornamental Plants and Turf; UNSW Press: Randwick, Australia, 2002.

35. Nelson, D.W.; Sommers, L.E.; Sparks, D.L.; Page, A.L.; Helmke, P.A.; Loeppert, R.H.; Soltanpour, P.N.; Tabatabai, M.A.; Johnston, C.T.; Sumner, M.E. Total carbon, organic carbon, and organic matter. Methods Soil Anal. 1982, 9, 961-1010.

36. Sparks, D.L.; Page, A.; Helmke, P.; Loeppert, R.; Soltanpour, P.; Tabatabai, M.; Johnston, C.; Sumner, M. Methods of Soil Analysis, Part 3, Chemical Methods; Soil Science Society of America Madison: Madison, WI, USA, 1996.

37. Watanabe, F.S.; Olsen, S.R. Test of an Ascorbic Acid Method for Determining Phosphorus in Water and NaHCO3 Extracts from Soil1. Soil Sci. Soc. Am. J. 1965, 29, 677-678. [CrossRef]

38. Knudsen, D.; Peterson, G.; Pratt, P. Lithium, sodium, and potassium. In Methods of Soil Analysis, Part 2, Chemical and Microbiological Properties; Page, A.L., Miller, R.H., Kenney, D.R., Eds.; American Society of Agronomy, Soil Science Society of American: Madison, WI, USA, 1982; pp. 225-246.

39. Mitchell, C.C.; Huluka, G. Potassium Dynamics in US Coastal Plain Soils. Commun. Soil Sci. Plant Anal. 2016, 47 (Suppl. 1), 54-63. [CrossRef]

40. Frostegård, A.; Bååth, E. The use of phospholipid fatty acid analysis to estimate bacterial and fungal biomass in soil. Biol. Fertil. Soils 1996, 22, 59-65. [CrossRef]

41. Chen, D.; Lan, Z.; Hu, S.; Bai, Y. Effects of nitrogen enrichment on belowground communities in grassland: Relative role of soil nitrogen availability vs. soil acidification. Soil Biol. Biochem. 2015, 89, 99-108. [CrossRef]

42. Friendly, M.; Fox, J.; Friendly, M.M. Visualizing Generalized Canonical Discriminant and Canonical Correlation Analysis. $R$ Package Candisc Version: 0.6-5. 2013. Available online: https:/ / cran.r-project.org/web/packages/candisc/candisc.pdf (accessed on 15 May 2021).

43. Rosseel, Y. Lavaan: An R Package for Structural Equation Modeling. J. Stat. Softw. 2012, 48, 1-36. [CrossRef]

44. Barnes, R.T.; Gallagher, M.E.; Masiello, C.A.; Liu, Z.; Dugan, B. Biochar-Induced Changes in Soil Hydraulic Conductivity and Dissolved Nutrient Fluxes Constrained by Laboratory Experiments. PLoS ONE 2014, 9, e108340. [CrossRef] [PubMed]

45. Berndtsson, J.C.; Bengtsson, L.; Jinno, K. Runoff water quality from intensive and extensive vegetated roofs. Ecol. Eng. 2009, 35, 369-380. [CrossRef]

46. Beck, D.A.; Johnson, G.R.; Spolek, G.A. Amending greenroof soil with biochar to affect runoff water quantity and quality. Environ. Pollut. 2011, 159, 2111. [CrossRef] 
47. Kuoppamäki, K.; Lehvävirta, S. Mitigating nutrient leaching from green roofs with biochar. Landsc. Urban Plan. 2016, 152, 39-48. [CrossRef]

48. Curtin, D.; Trolove, S. Predicting pH buffering capacity of New Zealand soils from organic matter content and mineral characteristics. Soil Res. 2013, 51, 494. [CrossRef]

49. Liu, T.; Guo, R.; Ran, W.; Whalen, J.K.; Li, H. Body size is a sensitive trait-based indicator of soil nematode community response to fertilization in rice and wheat agroecosystems. Soil Biol. Biochem. 2015, 88, 275-281. [CrossRef]

50. Cross, A.; Sohi, S.P. The priming potential of biochar products in relation to labile carbon contents and soil organic matter status. Soil Biol. Biochem. 2011, 43, 2127-2134. [CrossRef]

51. Nguyen, B.T.; Lehmann, J.; Kinyangi, J.; Smernik, R.; Riha, S.J.; Engelhard, M.H. Long-term black carbon dynamics in cultivated soil. Biogeochemistry 2009, 92, 163-176. [CrossRef]

52. Watzinger, A.; Feichtmair, S.; Kitzler, B.; Zehetner, F.; Kloss, S.; Wimmer, B.; Zechmeister-Boltenstern, S.; Soja, G. Soil microbial communities responded to biochar application in temperate soils and slowly metabolized $13 \mathrm{C}$-labelled biochar as revealed by 13 C PLFA analyses: Results from a short-term incubation and pot experiment. Eur. J. Soil Sci. 2014, 65, 40-51. [CrossRef]

53. Liang, B.; Lehmann, J.; Solomon, D.; Kinyangia, J.; Grossmana, J.; O’Neilla, B.; Skjemstadb, J.O.; Thiesa, J.; Luizãoc, F.J.; Petersend, J.; et al. Black carbon increases cation exchange capacity in soil. Soil Sci. Soc. Am. J. 2006, 70, 1719-1730. [CrossRef]

54. Novak, J.M.; Busscher, W.J.; Laird, D.L.; Ahmedna, M.; Watts, D.W.; Niandou, M.A.S. Impact of biochar amendment on fertility of a southeastern coastal plain soil. Soil Sci. 2009, 174, 105-112. [CrossRef]

55. Kolton, M.; Harel, Y.M.; Pasternak, Z.; Graber, E.R.; Elad, Y.; Cytryn, E. Impact of biochar application to soil on the root-associated bacterial community structure of fully developed greenhouse pepper plants. Appl. Environ. Microbiol. 2011, 77, 4924-4930. [CrossRef] [PubMed]

56. Bruun, E.W.; Petersen, C.T.; Hansen, E.; Holm, J.K.; Hauggaardnielsen, H. Biochar amendment to coarse sandy subsoil improves root growth and increases water retention. Soil Use Manag. 2014, 30, 109-118. [CrossRef]

57. Mulcahy, D.N.; Mulcahy, D.L.; Dietz, D. Biochar soil amendment increases tomato seedling resistance to drought in sandy soils. J. Arid Environ. 2013, 88, 222-225. [CrossRef] 